\title{
Studies on the metabolism of essential fatty acids in isolated human testicular cells
}

\author{
K. Retterstø| ${ }^{1}$, T. B. Haugen ${ }^{2}$, T. N. Tran ${ }^{1}$ \\ and B. O. Christophersen ${ }^{1}$ \\ ${ }^{1}$ Institute of Clinical Biochemistry, Andrology Laboratory, and ${ }^{2}$ Department of Gynaecology \\ and Obstetrics, National Hospital, University of Oslo, NO-0027 Oslo, Norway
}

The essential fatty acid 22:6(n-3) is a minor component of the Western diet, but a major fatty acid in human testis and semen. In mature spermatozoa, the physical and fusogenic properties of the plasma membrane are probably influenced by its particular fatty acid composition. In this study, the synthesis of 22:6(n-3) and 22:5(n-6) was investigated in isolated human testicular cells. $\left[1-{ }^{14} \mathrm{C}\right] 20: 4(\mathrm{n}-6)$, $\left[1-{ }^{14} \mathrm{C}\right] 20: 5(\mathrm{n}-3), \quad\left[1-{ }^{14} \mathrm{C}\right] 22: 4(\mathrm{n}-6)$ and $\left[1-{ }^{14} \mathrm{C}\right] 22: 5(\mathrm{n}-3)$ were incubated in a 'crude' cell suspension (consisting of a mixture of the cells in the seminiferous tubule), and in fractionated pachytene spermatocytes and round spermatids. The esterification of fatty acids in lipid and phospholipid classes and the fatty acid chain elongation and desaturation were measured. The crude cell suspension metabolized the fatty acids more actively than did the fractionated germ cell suspension, indicating that types of cell other than the germ cells are important for fatty acid elongation and desaturation and thus the production of 22:6(n-3). This finding is in agreement with previous results in rats that indicated that the Sertoli cells are the most important type of cell for the metabolism of essential fatty acids in the testis. Some $\left[1-{ }^{14} \mathrm{C}\right] 20: 5(\mathrm{n}-3)$ was elongated to $\left[{ }^{14} \mathrm{C}\right] 22: 5(n-3)$ in the fractionated germ cells, but very little was elongated further to $\left[{ }^{14} C\right] 24: 5(n-3)$, possibly restricting the formation of $\left[{ }^{14} \mathrm{C}\right] 22: 6(\mathrm{n}-3)$. In the fractionated germ cells, the fatty acid substrates were recovered primarily in the phospholipid fraction, indicating an incorporation in the membranes, whereas in the crude cells, more substrates were esterified in the triacylglycerol fraction. In the phospholipids, more radioactivity was recovered in phosphatidylcholine than in phosphatidylethanolamine and more radioactivity was recovered in phosphatidylethanolamine than in phosphatidylinositol or phosphatidylserine.

\section{Introduction}

In cell membranes, fatty acids are both structural elements and bioactive compounds. It has long been known that (n-6) fatty acids are essential for testis development and fertility (Burr and Burr, 1929; Evans et al., 1934). The testis has a high content of 20 and 22 carbon atom polyunsaturated fatty acids (PUFA) and the PUFA further accumulate in semen. In testis of rats (Chanmugam et al., 1991), rabbits and other rodents (Ahluwalia and Holman, 1969), the (n-6) PUFA dominate, and the testes from these species have a high content of 22:5(n-6). However, in testis of humans (Ahluwalia and Holman, 1969; Coniglio et al., 1975; Nissen et al., 1978), monkeys (Connor et al., 1997), rams (Scott, 1973), bulls (Scott, 1973) and pigs (Paulenz et al., 1995) the (n-3) PUFA dominates. In these species, the amount of $22: 6(n-3)$ is high.

In whole human testis, $8-24 \%$ of the fatty acids are 22:6(n-3) (Bieri and Prival, 1965) and a low concentration of PUFA in semen has been associated with poor sperm quality. In normal human semen, up to $58 \%$ of the fatty acids are 22:6(n-3) (Nissen and Kreysel, 1983), and in the

Email: kjetil.retterstol@rh.uio.no phospholipids of spermatozoa recovered from $47 \%$ Percoll fractions, the content of 22:6(n-3) in normozoospermic semen was $22 \%$ compared with $16 \%$ in oligozoospermic semen (Zalata et al., 1998). Speculation about the function of PUFA in testis has been related to their possible effect on the fluidity of the sperm membrane and the packing of membrane-bound receptors. 22:6(n-3) increases the membrane fluidity, and this may also contribute to the motility of the spermatozoa (Connor et al., 1998).

Studies have been performed on the metabolism of essential fatty acids in the testis of rats, but little is known about it in human testis. Fatty acid synthesis has been demonstrated in human whole testis tissue incubated with $\left[1-{ }^{14} \mathrm{C}\right]$ acetate (Fisher and Coniglio, 1983). Furthermore, both human whole testis tissue and microsomal preparations can synthesize arachidonic acid from labelled precursors (Coniglio et al., 1977; Albert et al., 1979). The pathway for the synthesis of 22:6(n-3) (Voss et al., 1991) and 22:5(n-6) (Mohammed et al., 1995) has been reported but little is known about its regulation. The present study investigated this revised pathway in human testis. To the authors' knowledge, this is the first study on the synthesis and metabolism of 22:6(n-3) and 22:5(n-6) in human testicular cells. 
Studies on rats indicate that Sertoli cells are more important than germ cells for the formation of PUFA (Beckman and Coniglio, 1980; Retterstøl et al., 1998, 2000). In the present study, various cell types of seminiferous tubules were used to examine the origin of PUFA in human testis.

\section{Materials and Methods}

\section{Chemicals}

$\left[1-{ }^{14} \mathrm{C}\right] 20: 4(\mathrm{n}-6),\left[1{ }^{-14} \mathrm{C}\right] 20: 5(\mathrm{n}-3),\left[1{ }^{14} \mathrm{C}\right] 22: 4(\mathrm{n}-6)$ and [1- $\left.{ }^{14} \mathrm{C}\right] 22: 5(\mathrm{n}-3)$ were obtained from American Radiolabeled Chemicals Inc. (St Louis, MO), and the unlabelled fatty acids were from Sigma Chemicals Co. (St Louis, MO).

\section{Preparation of cell suspensions}

Testicular material was obtained from four organ donors (aged 45-61) in connection with donation of multiple organs after brain death according to a procedure approved by the local ethical committee. Each testicle was studied separately. Data about the organ donors are spare, but the testis had a normal macroscopic appearance and a normal weight (11-28 g after decapsulation). Furthermore, acceptance as an organ donor requires good health before death. A 'crude' germ cell suspension, consisting of a mixture of the cells in the seminiferous tubule, was prepared by treatment with trypsin and DNase (Meistrich, 1977). The germ cells were fractionated further by centrifugal elutriation (Blanchard et al., 1991) to $75-83 \%$ (range) purity of haploid cells (1300-450 $\mathrm{g}$ and $22.8-45.5 \mathrm{ml} \mathrm{min}-1)$. Elutriation is a counterflow centrifugation which means that the sedimentation of cells in a centrifugal field is offset by a liquid flowing in the opposite direction. The cell densities in the isolated germ cell and the testis crude suspensions were $0.77-0.97$ and $2.7-11.0 \times 10^{6}$ cells $\mathrm{ml}^{-1}$, respectively, and the corresponding mean protein concentrations were $0.40-0.43$ and $1.2-4.7 \mathrm{mg} \mathrm{ml}^{-1}$, respectively. Five millilitres of this preparation was used for incubation in NUNC $50 \mathrm{ml}$ cell culture flasks. The suspensions contained $1.5 \%(\mathrm{w} / \mathrm{v})$ essentially fatty acid free BSA. Twenty nanomoles of radiolabelled fatty acid with a specific activity of approximately $55 \mathrm{mCi} \mathrm{mmol}^{-1}$ was added to each flask (the fatty acid concentration was $\left.4 \mu \mathrm{mol} \mathrm{I}^{-1}\right)$.

\section{Analytical methods}

Lipids were extracted (Folch et al., 1957) and aliquots were separated on silicic acid thin-layer plates (Stahl $\mathrm{H}+$ ) with hexane-diethylether-acetic acid (70:29:1, v/v) and counted in an imager scanner from Packard. The phospholipids were isolated using the same thin liquid chromatography (TLC) system and eluted with $2 \times 2 \mathrm{ml}$ $\mathrm{CHCl}_{3}-\mathrm{MeOH}$-acetic acid-water (50:39:1:10, v/v). The phospholipid was separated further into phosphatidylinositol (Ptdlns), phosphatidylserine (PtdSer), phosphatidylcholine (PtdCho) and phosphatidylethanolamine (PtdEtn) on Whatman LK5 thin layer plates with $\mathrm{CHCl}_{3}-\mathrm{MeOH}-40 \%$ methylamine (120:40:10, v/v) as solvent. The Whatman LK5 thin layer plates were scanned and thereafter the phospholipid classes were eluted with $2 \times 2 \mathrm{ml}$ $\mathrm{CHCl}_{3}-\mathrm{MeOH}$-acetic acid-water (50:39:1:10, v/v).

Aliquots of the total lipids of the cell suspensions, the isolated cells and the isolated media, as well as the phospholipid and triacylglycerol (TAG) fractions were transmethylated $\left(\mathrm{BF}_{3}-\right.$ methanol) and the fatty acids were separated with primary reverse phase HPLC (isocratically) on a Supelcosil LC-18 (250 mm length $\times 4.6 \mathrm{~mm}$ diameter) reversed phase column (Supelco, Bellfonte, PA). The mobile

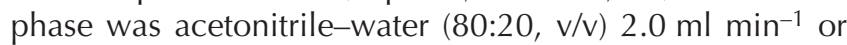
acetonitrile-water (90:10, v/v) $0.75 \mathrm{ml} \mathrm{min}^{-1}$ delivered by a LC-9A Shimadzu apparatus (Kyoto). Radioactivity was measured in a flow detector A-100 (Radiomatic Instruments and Chemical, Tampa, FL). The fatty acids were identified by comparing their retention times with those from $\left[1-{ }^{14} \mathrm{C}\right]-$ labelled fatty acid standards and with retention times from previous experiments.

Determination of radioactive acid soluble products and of radioactive $\mathrm{CO}_{2}$ (as a measure of the rate of oxidation of carbon one) was performed as described by Christiansen et al. (1976). Flasks in which the formation of radioactive $\mathrm{CO}_{2}$ was to be measured had a centre well containing $0.2 \mathrm{ml}$ of $10 \% \mathrm{NaOH}$ and a folded filter paper, and a side arm containing $0.2 \mathrm{ml}$ of $5 \mathrm{~mol} \mathrm{HClO}_{4} \mathrm{I}^{-1}$. At the end of the

Table 1. Amounts of $\left[1-{ }^{14} \mathrm{C}\right]$ fatty acid esterified and elongated in the lipid extract of cells plus medium after 24 h of incubation in a 'crude' cell suspension

\begin{tabular}{lccc}
\hline Substrate & $\begin{array}{c}\text { Nanomoles of fatty acid } \\
\text { esterified (\%) }\end{array}$ & $\begin{array}{c}\text { Nanomoles of fatty acid } \\
\text { elongated (\%) }\end{array}$ & $\begin{array}{c}\text { Number of } \\
\text { incubations }\end{array}$ \\
\hline $20: 4(\mathrm{n}-6)$ & $9.6 \pm 2.1(51)$ & $0.6 \pm 0.3(6)^{*}$ & 8 \\
$20: 5(\mathrm{n}-3)$ & $8.6 \pm 1.4(56)$ & $2.7 \pm 1.7(31)$ & 7 \\
$22: 4(\mathrm{n}-6)$ & $11.8 \pm 2.7(69)$ & $1.2 \pm 0.3(10)$ & 8 \\
$22: 5(\mathrm{n}-3)$ & $12.1 \pm 3.7(71)$ & $1.9 \pm 1.1(16)$ & 8 \\
\hline
\end{tabular}

Values are means $\pm 1 \mathrm{SD}$.

*20:4(n-6) was elongated less than 20:5(n-3), $P<0.05$. 
Table 2. Amounts of $\left[1-{ }^{14} \mathrm{C}\right]$ fatty acid esterified and elongated in the lipid extract of cells plus medium after $24 \mathrm{~h}$ of incubation in a suspension of isolated pachytene spermatocytes (PS) or round spermatids (RST)

\begin{tabular}{lccc}
\hline Substrate & $\begin{array}{c}\text { Nanomoles of fatty acid } \\
\text { esterified (\%) }\end{array}$ & $\begin{array}{c}\text { Nanomoles of fatty acid } \\
\text { elongated (\%) }\end{array}$ & $\begin{array}{c}\text { Number of } \\
\text { incubations }\end{array}$ \\
\hline PS & & & $0.8 \pm 0.4(21)$ \\
$20: 4(\mathrm{n}-6)$ & $3.8 \pm 0.1(20)^{*}$ & $0.9 \pm 0.3(26)$ & 5 \\
$20: 5(\mathrm{n}-3)$ & $3.4 \pm 0.2(17)^{*}$ & & 5 \\
RST & & $0.2 \pm 0.2(11)$ & 5 \\
$20: 4(\mathrm{n}-6)$ & $1.8 \pm 0.1(10)$ & $0.1 \pm 0.1(6)$ & 5 \\
$20: 5(\mathrm{n}-3)$ & $1.7 \pm 0.1(9)$ & & 5 \\
\hline
\end{tabular}

Values are means \pm 1 SD.

*Esterification in PS $>$ RST, $P<0.05$.

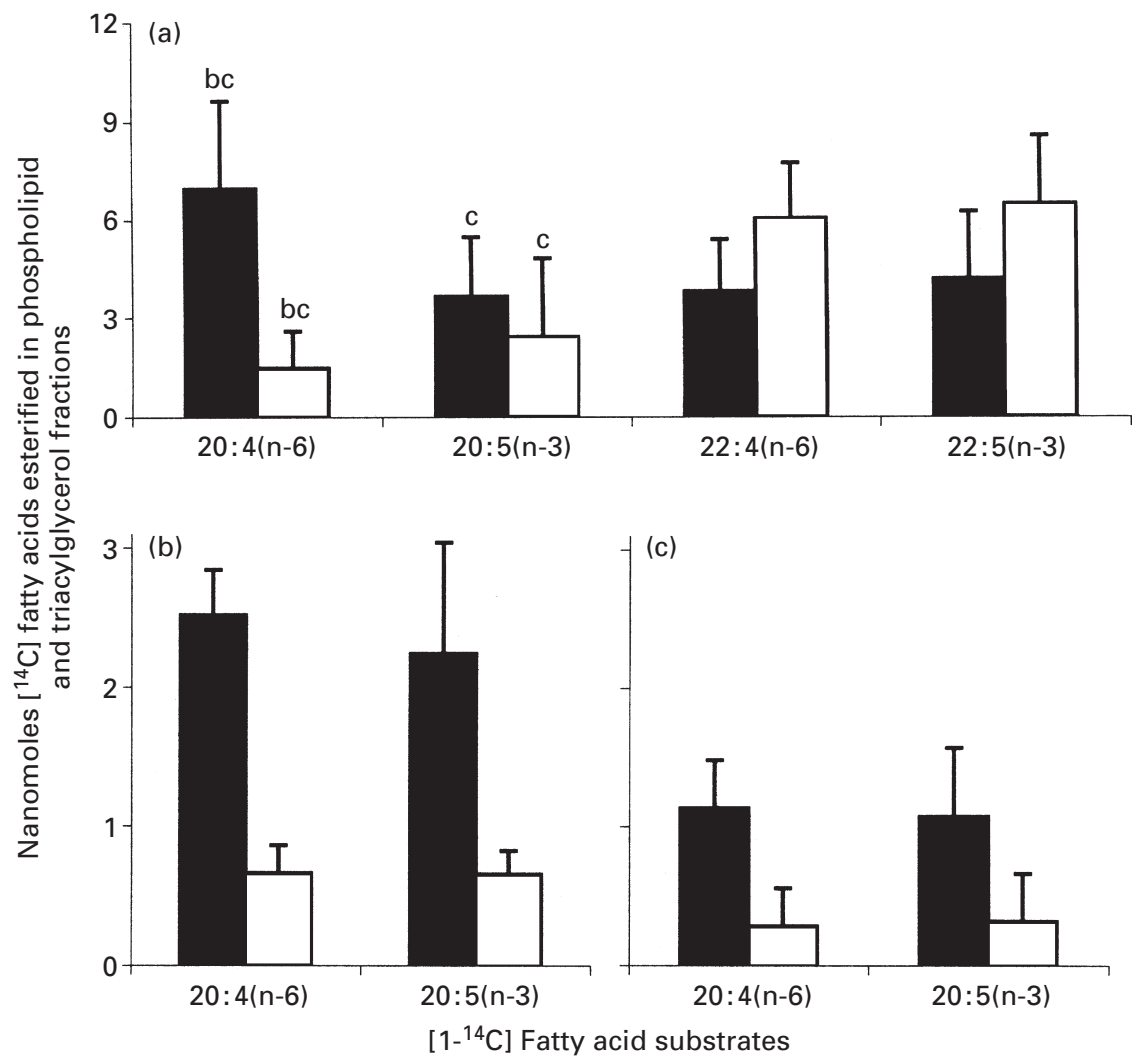

Fig. 1. (a) Nanomoles of $\left[1-{ }^{14} \mathrm{C}\right] 20: 4(\mathrm{n}-6),\left[1-{ }^{14} \mathrm{C}\right] 20: 5(\mathrm{n}-3),\left[1-{ }^{14} \mathrm{C}\right] 22: 4(\mathrm{n}-6)$ and $\left[1-{ }^{14} \mathrm{C}\right] 22: 5(\mathrm{n}-3)$ esterified in the phospholipid (PL; $\left.\mathbf{\square}\right)$ and triacylglycerol (TAG; $\square)$ fractions after $24 \mathrm{~h}$ of incubation in 'crude' cell suspension. (b,c) Nanomoles of $\left[1-{ }^{14} C\right] 20: 4(n-6)$ and $\left[1-{ }^{14} C\right] 20: 5(n-3)$ esterified in pachytene spermatocytes (b) and round spermatids $(\mathrm{c})$. Mean values from $5-9$ incubations $\pm 1 \mathrm{SD}$. ${ }^{\mathrm{b} P L}>\mathrm{TAG}$ $(P<0.05)$; $^{\mathrm{C}^{\prime}} \mathrm{Crude}^{\prime}>$ the two germ cell fractions $(P<0.05)$.

incubation, the $\mathrm{HClO}_{4}$ was tipped in and the shaking was continued for 60 min to trap all ${ }^{14} \mathrm{CO}_{2}$ in the filter paper. Thereafter, the filter paper was counted in a Packard TriCarb 1500 liquid analyser. Analyses on lipids and acid- soluble products were performed on an identical pair of incubation flasks. The acid soluble radioactivity was measured in the $\mathrm{HClO}_{4}$ extracts. Labelled oxidation products were also measured in the water phase of the lipid 
extraction. Cellular protein was determined according to the method of Lowry et al. (1951).

\section{Statistical analyses}

An unpaired, two-sided $t$ test was used. When multiple comparisons were performed the $P$ values were Bonferronicorrected.

\section{Results}

In the crude suspension, $6-31 \%$ of the esterified radiolabelled fatty acids were elongated (Table 1). More labelled fatty acid substrates were esterified and elongated in the crude cell suspension than in the fractionated germ cell suspensions $(P<0.05$, Table 1 versus Table 2 ; and pachytene spermatocytes $>$ round spermatids, $P<0.05$, Table 2).

In the crude cell suspension, more $\left[{ }^{14} \mathrm{C}\right] 22: 4(n-6)$ and $\left[{ }^{14} \mathrm{C}\right] 22: 5(\mathrm{n}-3)$ was esterified in the TAG than in the phospholipid fraction $(P<0.05$, Fig. 1a). In the fractionated germ cells, more $\left[{ }^{14} C\right] 20: 5(n-3)$ and $\left[{ }^{14} C\right] 20: 4(n-6)$ was esterified in the phospholipid than in the TAG fraction $\left(P<0.05\right.$, Fig. 1b,c). $\left[{ }^{14} \mathrm{C}\right] 20: 4(\mathrm{n}-6)$ was the best substrate for esterification in phospholipids (Fig. 1), and little $\left[{ }^{14} \mathrm{C}\right] 20: 4(n-6)$ was oxidized compared with $\left[{ }^{14} \mathrm{C}\right] 20: 5(n-3)$ $(0.6 \pm 0.5$ versus $1.8 \pm 0.4$ nmoles $)$. In the crude cell suspension and the fractionated germ cell suspension, 0.3-0.5 nmoles and 0.1-0.2 nmoles, respectively, were esterified in the diacylglycerol fraction, and 0.08-0.15 nmoles and 0.01-0.02 nmoles, respectively, were esterified in the cholesterol ester fraction.

More fatty acid substrates were esterified in PtdCho than in PtdEtn, PtdSer and PtdIns in all cell fractions (Fig. 2).

The most active elongation activity was found to be from $\left[{ }^{14} \mathrm{C}\right] 20: 5(\mathrm{n}-3)$ to $\left[{ }^{14} \mathrm{C}\right] 22: 5(\mathrm{n}-3)$ in the TAG fraction of the crude cell suspension (Fig. 3b). In the fractionated germ cells, the degree of elongated fatty acid substrates seemed to be highest in the TAG fraction, although little was esterified in this lipid class (Fig. 4). Very little $\mathrm{C}_{24}$ fatty acid and $\left[{ }^{14} \mathrm{C}\right] 22: 5(n-6)$ or $\left[{ }^{14} \mathrm{C}\right] 22: 6(n-3)$ were formed in either the fractionated germ cells or the crude cell suspensions (Figs 3 and 4), indicating a low capacity both for the elongation reaction from 22 to 24 carbon fatty acids and for the $\Delta 6$ desaturation.

\section{Discussion}

The present results are from experiments performed on separate testicular material from four men. In spite of the differences among these testes, large differences in fractionated cells were not expected.

Data from studies in rats indicate that the synthesis of 22:5(n-6) and 22:6(n-3) is very efficient in Sertoli cells, while germ cells are considerable less active (Beckman and Coniglio, 1980; Retterstøl et al., 2000), in agreement with the hypothesis of a transport of PUFA from the Sertoli cells to the germ cells (Beckman et al., 1978). In the present study, almost no 22:5(n-6) and 22:6(n-3) were formed by fractionated human germ cells indicating that, in humans also, the Sertoli cell is important for the conversion of essential fatty acids in the testis. In human germ cells, the content of 22:6(n-3) increased with increasing maturity (Lenzi et al., 2000). A considerable lipid remodelling of rat spermatozoa has been shown to occur during their journey through the epididymis (Hall et al., 1991; Aveldano et al., 1992), and an active role of the epididymis in humans is indicated by the high concentration of carnitine in human epididymis, as discussed by Lenzi et al. (2000).

Fatty acid metabolic activity in the human testicular cells was low compared with that found in rats (Retterstøl et al., 1998). Therefore, it is possible that human cells have a lower capacity for metabolizing fatty acid substrates than rat cells, which would not be surprising since the testis of adult rats accounts for approximately $0.7 \%$ of the body weight compared with approximately $0.04 \%$ of the body weight in men (Fredricsson and Pousette, 1994). Furthermore, the daily sperm production per gram testis is 5-6 times greater in rats than it is in men (Sharpe, 1994).

$\left[{ }^{14} \mathrm{C}\right] 20: 4(n-6)$ was esterified efficiently in phospholipids, which may reflect a stable incorporation in the membranes, and this fatty acid is also normally present in relatively high quantities in human testis in vivo (Coniglio et al., 1975). However, $\left[{ }^{14} \mathrm{C}\right] 22: 4(\mathrm{n}-6)$ and $\left[{ }^{14} \mathrm{C}\right] 22: 5(\mathrm{n}-3)$ were primarily esterified in the TAG fraction, and little of these fatty acids is found in human testis in vivo, reflecting the lesser degree of incorporation in the cell membranes. The same differences between these fatty acids have been demonstrated in isolated rat hepatocytes (Retterstøl et al., 1995).

Although the testicular cells of rats seemed to be more active than those of men, many similarities between the two species were found. In the fractionated human germ cells only, a higher proportion of the substrate was esterified in the phospholipid than in the TAG fraction. These results resemble those reported in studies of rat testicular cells. In the phospholipids of the human testicular cells, the fatty acid substrates were mainly esterified in PtdCho, which is similar to the situation in rats. In the germ cells from men, pachytene spermatocytes were more active in metabolizing the fatty acids than were the round spermatids, and this was also similar to the situation in rats.

Sprecher (1999) has shown that 22:4(n-6) and 22:5(n-3) are not desaturated at position 4 as was believed for many years, but elongated to 24-carbon fatty acid intermediates and then desaturated at position 6 . Little is known about the regulation of this revised pathway from $20: 5(n-3) \rightarrow 22: 5$ (n$3) \rightarrow 24: 5(n-3) \rightarrow 24: 6(n-3) \rightarrow 22: 6(n-3)$. The present data indicate that $20: 5(n-3)$ is a better substrate for fatty acid elongation than 20:4(n-6) in human testis, facilitating the synthesis of $22: 6(n-3)$ over that of $22: 5(n-6)$. However, the next elongation, from 22:5(n-3) to 24:5(n-3), was inefficient, possibly restricting the formation of both 22:5(n-6) and 22:6(n-3). The next step in the pathway is the $\Delta 6$ desaturation, and this activity is lower in isolated rat 


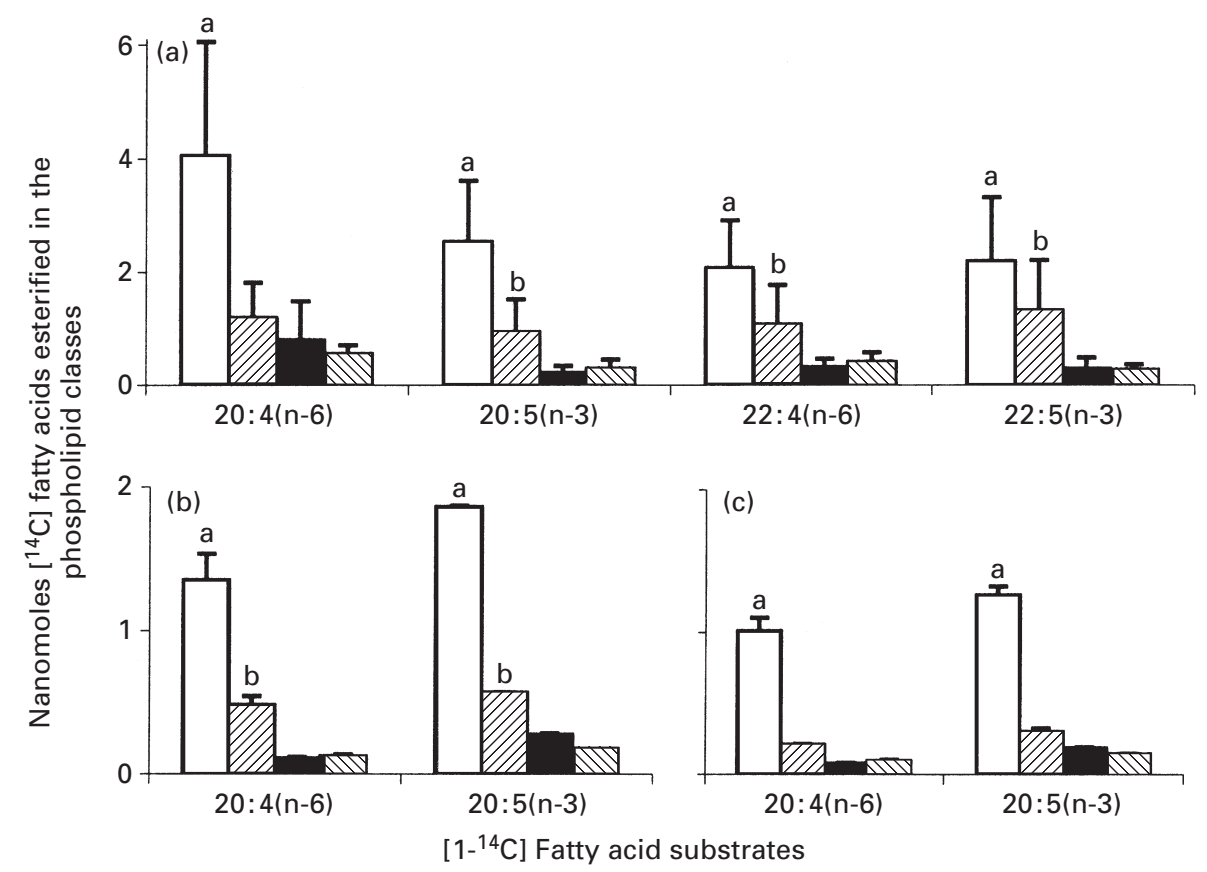

Fig. 2. (a) Nanomoles of $\left[1-{ }^{14} C\right] 20: 4(n-6),\left[1-{ }^{14} C\right] 20: 5(n-3),\left[1-{ }^{14} C\right] 22: 4(n-6)$ and $[1-$ $\left.{ }^{14} \mathrm{C}\right] 22: 5(\mathrm{n}-3)$ esterified in phosphatidylcholine (PtdCho; $\square$ ), phosphatidylethanolamine

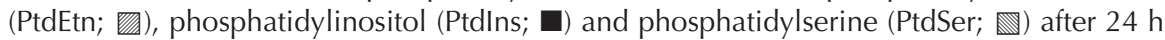
of incubation in 'crude' cell suspension. (b,c) Nanomoles of $\left[1-{ }^{14} \mathrm{C}\right] 20: 4(\mathrm{n}-6)$ and [1$\left.{ }^{14} \mathrm{C}\right] 20: 5(\mathrm{n}-3)$ esterified in the same phospholipid classes in pachytene spermatocytes (b) and round spermatids (c). Mean values from 5-9 incubations \pm 1 SD. ${ }^{\text {a }}$ tdCho $>\operatorname{PtdEtn}(P<0.05)$; betdEtn $>$ PtdIns and PtdSer $(P<0.05)$.

(a)

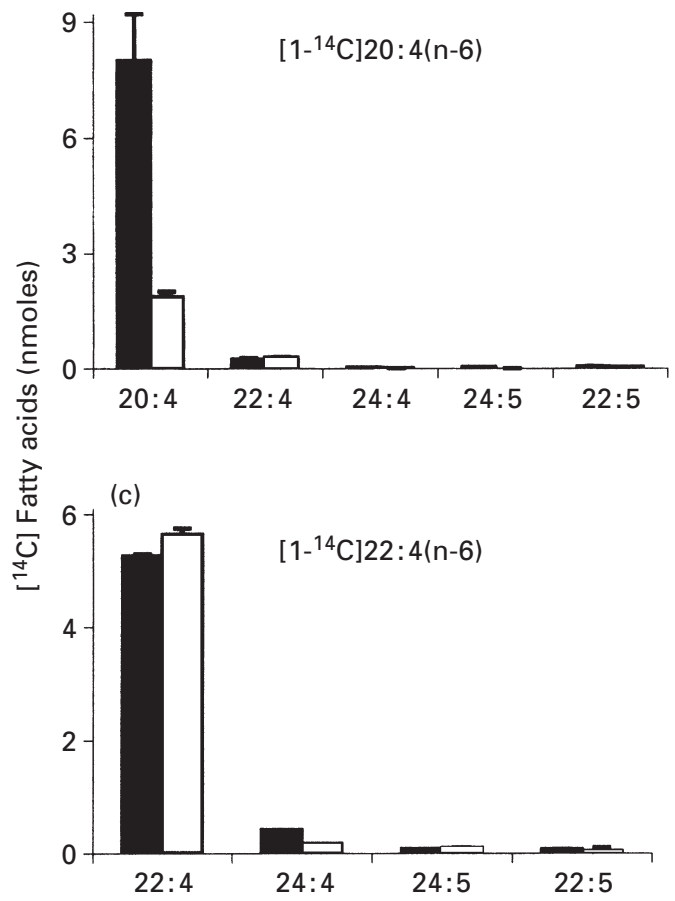

(b)
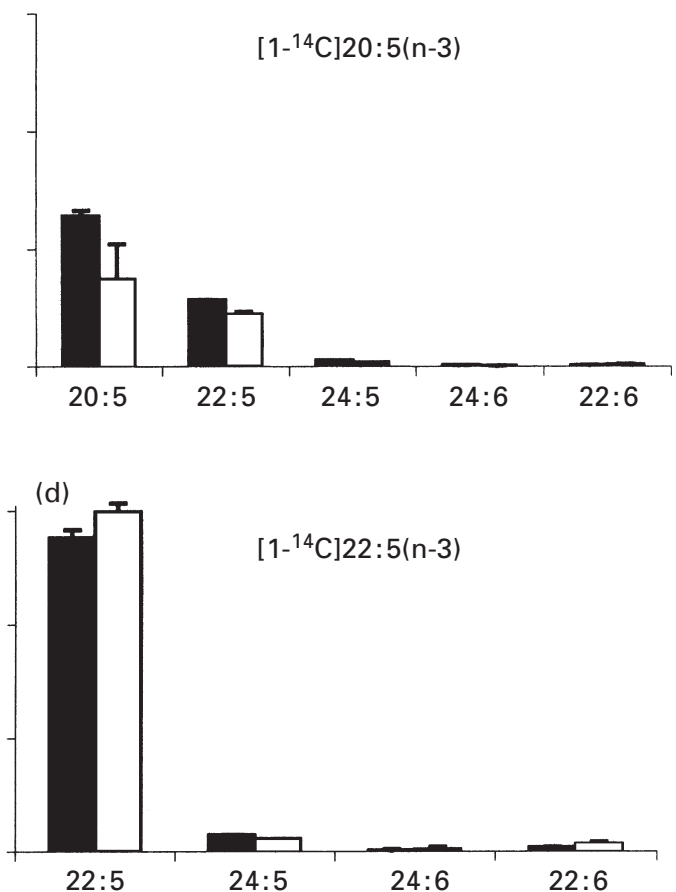

Fig. 3. The elongation and desaturation of (a) $\left[1-{ }^{14} C\right] 20: 4(n-6),(b)[1-14 C] 20: 5(n-3)$, (c) $[1-14 C] 22: 4(n-6)$, and $(d)\left[1-{ }^{14} \mathrm{C}\right] 22: 5(n-3)$ incubated in the testis 'crude' cell suspension and esterified in the phospholipid (ם) or the triacylglycerol $(\square)$ fractions. Mean values from 3-9 incubations \pm 1 SD. 
(a)

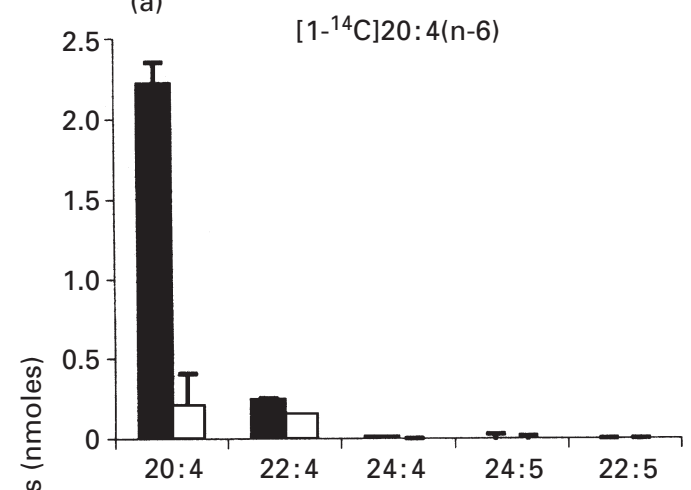

(c)

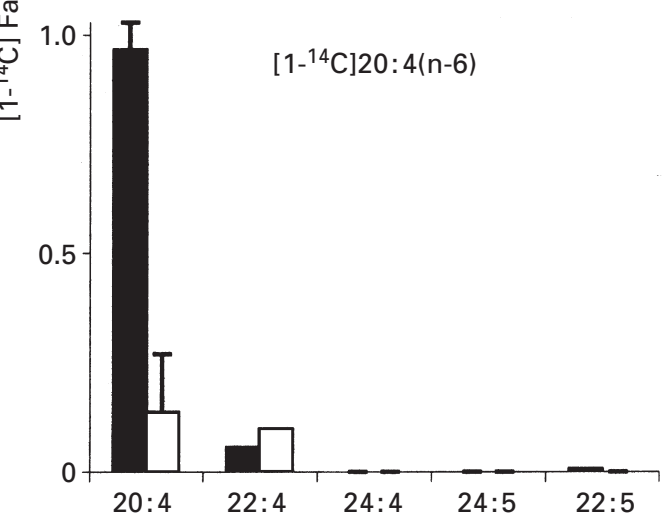

(b)

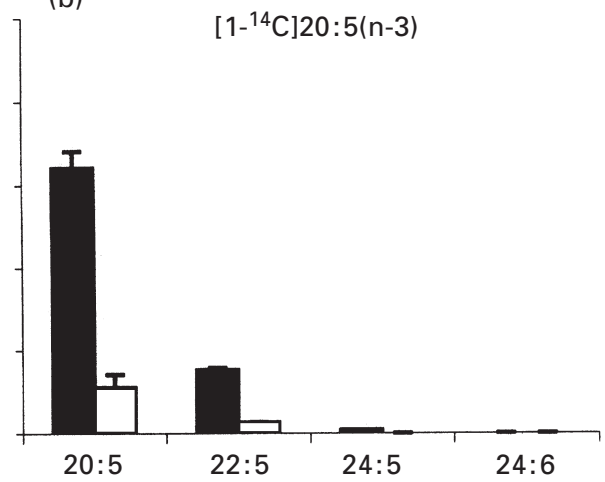

(d)

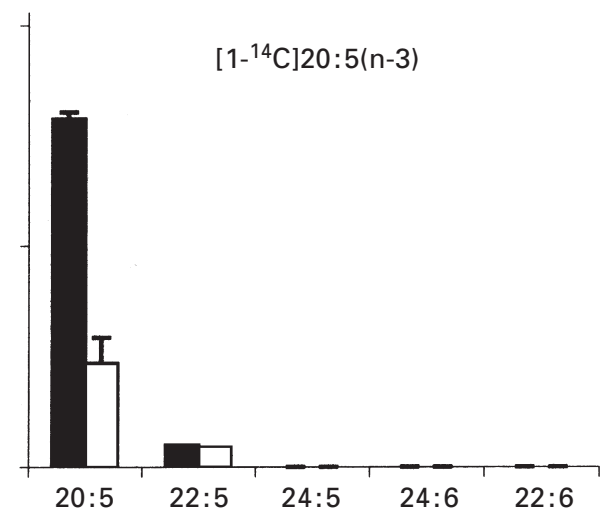

Fig. 4. The elongation and desaturation of (a) $\left[1-{ }^{14} C\right] 20: 4(n-6)$, (b) $\left[1-{ }^{14} C\right] 20: 5(n-3)$, (c) $[1-$ $\left.{ }^{14} \mathrm{C}\right] 20: 4(\mathrm{n}-6)$ and $(\mathrm{d})\left[1-{ }^{14} \mathrm{C}\right] 20: 5(\mathrm{n}-3)$ incubated in the isolated germ cell suspension $(\mathrm{a}, \mathrm{b}$ : pachytene spermatocytes; c,d: round spermatids) and esterified in the phospholipid (ם) or the triacylglycerol $(\square)$ fractions. Mean values from 4-5 incubations \pm 1 SD.

germ cells than it is in Sertoli cells (Retterstøl et al., 2000). The present results indicate a similiar situation in men. The human $\Delta 6$ desaturase gene has recently been cloned (Cho et al., 1999) and there is a low $\triangle 6$ mRNA concentration in isolated rat germinal cells compared with isolated rat Sertoli cells (T. N. Tran, unpublished).

In conclusion, almost no 22:6(n-3) was synthesized by the human germ cells. This finding is probably related to a low capacity for fatty acid elongation and possibly also the $\Delta 6$ desaturation. The high concentrations of 22:6(n-3) and other polyunsaturated fatty acids found in human germ cells in vivo may be strictly related to their normal function and morphology (Lenzi et al., 2000), and the present results indicate that germ cells are dependent on a supply of this fatty acid, most likely from the surrounding Sertoli cells.

The authors are grateful to Anne-Marie Lund and Siri Tverdal for excellent technical work.

\section{References}

Ahluwalia B and Holman RT (1969) Fatty acid composition of lipids of bull, boar, rabbit and human semen Journal of Reproduction and Fertility $\mathbf{1 8}$ 431-437

Albert DH, Rhamy RK and Coniglio JG (1979) Desaturation of eicosa-1114dienoic acid in human testes Lipids $\mathbf{1 4}$ 498-500

Aveldano MI, Rotstein NP and Vermouth NT (1992) Lipid remodelling during epididymal maturation of rat spermatozoa. Enrichment in plasmenylcholines containing long-chain polyenoic fatty acids of the n-9 series Biochemical Journal 283 235-241

Beckman JK and Coniglio JG (1980) The metabolism of polyunsaturated fatty acids in rat Sertoli and germinal cells Lipids 15 389-394

Beckman JK, Gray ME and Coniglio JG (1978) The lipid composition of isolated rat spermatids and spermatocytes Biochimica et Biophysica Acta $530367-374$

Bieri JG and Prival EL (1965) Lipid composition of testes from various species Comparative Biochemistry and Physiology 15 275-282

Blanchard Y, Lavault MT, Quernee D, Le Lannou D, Lobel B and Lescoat D (1991) Preparation of spermatogenic cell populations at specific stages of differentiation in the human Molecular Reproduction and Development 30 275-282 
Burr GO and Burr MM (1929) A new deficiency disease produced by the rigid exclusion of fat from the diet Journal of Biological Chemistry 82 345-367

Chanmugam PS, Boudreau MD and Hwang DH (1991) Dietary (n-3) fatty acids alter fatty acid composition and prostaglandin synthesis in rat testis Journal of Nutrition 121 1173-1178

Cho HP, Nakamura MT and Clarke SD (1999) Cloning expression and nutritional regulation of the mammalian Delta-6 desaturase Journal of Biological Chemistry 274 471-477

Christiansen R, Borrebaeck B and Bremer J (1976) The effect of (-) carnitine on the metabolism of palmitate in the liver cells isolated from fasted and refed rats FEBS Letters 62 313-317

Coniglio JG, Grogan WMJ and Rhamy RK (1975) Lipid and fatty acid composition of human testes removed at autopsy Biology of Reproduction 12 255-259

Coniglio JG, Whorton AR and Beckman JK (1977) Essential fatty acids in testes Advances in Experimental Medicine and Biology 83 575-589

Connor WE, Lin DS and Neuringer M (1997) Biochemical markers for puberty in the monkey testis: desmosterol and docosahexaenoic acid Journal of Clinical Endocrinology and Metabolism 82 1911-1916

Connor WE, Lin DS, Wolf DP and Alexander M (1998) Uneven distribution of desmosterol and docosahexaenoic acid in the heads and tails of monkey sperm Journal of Lipid Research 39 1404-1411

Evans HM, Lepovsky S and Murphy S (1934) Vital need of the body for certain unsaturated fatty acids VI. Male sterility on fat-free diets Journal of Biological Chemistry 106 445-449

Fisher DM and Coniglio JG (1983) Composition of and $\left[{ }^{14} \mathrm{C}\right]$ acetate incorporation into lipids of rat Sertoli cells in culture Biochimica et Biophysica Acta 751 27-32

Folch JM, Lees M and Sloane Stanley GH (1957) A simple method for the isolation and purification of total lipids from animal tissue Journal of Biological Chemistry 226 497-509

Fredricsson B and Pousette Å (1994) Andrologi pp 54-54 AlmquistandWiksell Medicin, Falkøping

Hall JC, Hadley J and Doman T (1991) Correlation between changes in rat sperm membrane lipids protein and the membrane physical state during epididymal maturation Journal of Andrology 12 76-87

Lenzi A, Gandini L, Maresca V, Rago R, Sgro P, Dondero F and Picardo M (2000) Fatty acid composition of spermatozoa and immature germ cells Molecular Human Reproduction 6 226-231

Lowry OH, Rosebrough NJ, Farr AL and Randall RJ (1951) Protein measurement with the folin phenol reagent Journal of Biological Chemistry 193 265-275

Meistrich ML (1977) Separation of spermiogenic cells and nuclei from rodent testis. In Methods in Cell Biology p 15 Ed. DM Prescott. Academic Press, New York

Mohammed BS, Sankarappa S, Geiger M and Sprecher H (1995)
Reevaluation of the pathway for the metabolism of $7,10,13,16$ docosatetraenoic acid to $4,7,10,13,16$-docosapentaenoic acid in rat liver Archives of Biochemistry and Biophysics 317 179-184

Nissen HP and Kreysel HW (1983) Polyunsaturated fatty acids in relation to sperm motility Andrologia 15 264-269

Nissen HP, Heinze I, Kreysel HW and Schirren C (1978) Fatty acid composition of neutral lipids of human semen [German] Andrologia $\mathbf{1 0}$ 390-392

Paulenz H, Taugbol O, Hofmo PO and Saarem K (1995) A preliminary study on the effect of dietary supplementation with cod liver oil on the polyunsaturated fatty acid composition of boar semen Veterinary Research Communications 19 273-284

Retterstøl K, Woldseth B and Christophersen BO (1995) Studies on the metabolism of $\left[1-{ }^{14} \mathrm{C}\right] 5.8 .11$-eicosatrienoic (Mead) acid in rat hepatocytes Biochimica et Biophysica Acta 1259 82-88

Retterstøl K, Haugen TB, Woldseth B and Christophersen BO (1998) A comparative study of the metabolism of n-9, n- 6 and n-3 fatty acids in testicular cells from immature rat Biochimica et Biophysica Acta 1392 59-72

Retterstøl K, Haugen TB and Christophersen BO (2000) The pathway from arachidonic to docosapentaenoic acid (20:4n-6 to $22: 5 n-6)$ and from eicosapentaenoic to docosahexaenoic acid (20:5n-3 to 22:6n-3) studied in testicular cells from immature rats Biochimica et Biophysica Acta $1483119-131$

Scott TW (1973) Lipid metabolism of spermatozoa Journal of Reproduction and Fertility Supplement $\mathbf{1 8}$ 65-76

Sharpe RM (1994) Regulation of spermatogenesis. In The Physiology of Reproduction Eds E Knobil and JD Neill p.1363. Raven Press Ltd, New York

Sprecher H (1999) An update on the pathways of polyunsaturated fatty acid metabolism Current Opinion in Clinical Nutrition and Metabolic Care $\mathbf{2}$ 135-138

Voss A, Reinhart M, Sankarappa S and Sprecher H (1991) The metabolism of $7,10,13,16,19$-docosapentaenoic acid to $4,7,10,13,16,19$ docosahexaenoic acid in rat liver is independent of a 4-desaturase Journal of Biological Chemistry 26619 995-20 000

Zalata AA, Christophe AB, Depuydt CE, Schoonjans F and Comhaire FH (1998) The fatty acid composition of phospholipids of spermatozoa from infertile patients Molecular Human Reproduction 4 111-118

Received 10 March 2000.

First decision 23 June 2000.

Revised manuscript received 24 January 2001.

Accepted 15 February 2001. 